\title{
Kajian literasi pengembangan multimedia pembelajaran interaktif berbasis game edukasi materi sistem tata surya kelas VII SMP
}

\author{
Rohmatul Ifani, Munzil*, A. M. Setiawan \\ Universitas Negeri Malang, Jl. Semarang No. 5 Malang, Jawa Timur, Indonesia \\ *Penulis korespondensi, Surel: munzil.fmipa@um.ac.id
}

Paper received: 01-04-2021; revised: 15-04-2021; accepted: 30-04-2021

\begin{abstract}
Abstrak
Penelitian ini bertujuan untuk melakukan kajian literatur pengembangan multimedia pembelajaran interaktif berbasis game edukasi metari sistem tata surya kelas VII SMP. Pengembangan bahan ajar dilakukan dengan menggunakan metode Alessi dan Trollip yang dikembangkan oleh M. Alessi dan Stanley R. Trollip. Metode pengembangan Alessi dan Trollip memiliki tiga tahapan yaitu: 1) Perencanaan (planning); 2) Desain (design); dan 3) Pengembangan (development) (Alessi\&Trollip, 2001). Metode pengembangan ini dikembangkan dengan mencakup aspek penting dari perencanaan proyek instruksional (Alessi \& Trollip, 2001). Metode pengembangan Alessi dan Trollip didesain untuk mengembangkan multimedia pembelajaran yang didalamnya menjelaskan tentang komponen-komponen multimedia seperti teks, gambar, animasi, dan video (multimedia).
\end{abstract}

Kata kunci: multimedia pembelajaran; metode Alessi dan Trollip; game edukasi

\section{Pendahuluan}

IPA pada hakikatnya dapat dimaknai sebagai proses, produk, serta sikap ilmiah (Trianto, 2010). Topik sistem tata surya terdapat dalam tes PISA bagian knowledge of science kategori earth and space system (OECD, 2013). Topik ini merupakan pengetahuan yang diperlukan untuk memahami dunia alam dan merasakan pengalaman dalam situasi pribadi, sosial dan global melalui konsep yang saling berinteraksi antar lain ilmu fisik, kehidupan, teknologi bumi dan ruang angkasa.

Media pendidikan merupakan penyalur pesan dan perangsang perhatian, perasaan, pikiran, serta kemauan siswa yang disengaja mampu mewujudkan proses belajar yang memiliki tujuan dan dapat dikendalikan (Miarso, 2007). Media pembelajaran pada proses pembelajaran mampu membangkitkan minat dan motivasi serta merangasang keinginan belajar yang mempengaruhi psikologis siswa. Proses belajar serta penyampaian materi akan menjadi efektif dengan adanya media pembelajaran (Wiratmojo, P., \& Sasonohardjo., 2002).

Multimedia dikatakan interaktif apabila ada perintah balik yang diberikan oleh media tersebut kepada penggunanya. Interaktivitas dalam mulimedia meliputi: (1) dilibatkannya pengguna (user) dalam proses interaksi dalam pemrograman aplikasi serta (2) Aplikasi informasi interaktif memiliki tujuan supaya pengguna hanya mendapatkan informasi yang diinginkan (Munir, 2015).

Keunggulan penggunaan multimedia pembelajaran interaktif sebagai media pembelajaran menurut Newby (2000), yaitu : (1) diberikannya pembelajaran yang menyediakan penyimpanan informasi yang baik; (2) karakteristik desain pembelajaran yang berbeda dari setiap siswa; (3) ditujukan secara langsung domain pembelajaran yang efektif; (4) dihadirkannya model pembelajaran yang realistis; (5) mampu meningkatkan motivasi siswa; (6) siswa dituntuk supaya menjadi individu yang mampu berinteraksi; (7) kegiatan 
pembelajaran yang condong individualis; (8) materi yang diberikan memiliki konsistensi; (9) siswa mampu mengendalikan kecepatan belajarnya sendiri.

Game edukasi merupakan permainan utamanya memiliki tujuan supaya minat belajar siswa dapat terpancing dalam materi pembelajaran dibarengi dengan bermain, sehingga materi pembelajaran dapat dipahami lebih mudah oleh siswa karena susana hati yang senang. Kuswardayan (2012) mengemukakan bahwa game edukasi dapat dijadikan sebagai media pembelajaran maupun pelatihan yang berusaha menyajikan nilai pendidikan dalam bentuk permainan. Dibandingkan penyampaian pembelajaran dalam bentuk ceramah, penggunaan multimedia pembelajaran yang berbasis game edukasi dapat meningkatkan hasil pengetahuan serta aktivitas siswa dalam pembelajaran (Andel dkk, 2013).

\section{Metode}

Tujuan penelitian dan pengembangan ini ialah melakukan kajian literatur pengembangan multimedia pembelajaran interaktif berbasis game edukasi materi sistem tata surya kelas VII SMP. Untuk mencapai tujuan tersebut digunakan metode penelitian kualitatif dengan cara wawancara. Hasil dari wawancara tersebut dikaitkan dengan literasi yang relevan.

Penelitian dan pengembangan ini dilakukan di SMP Taruna Dra. Zulaeha Probolinggo dengan melakukan wawancara kepada narasumber. Narasumber yang digunakan adalah narasumber guru dan narasumber siswa. Narasumber guru adalah guru IPA SMP Taruna Dra. Zulaeha, sedangkan narasumber siswa adalah siswa kelas VII A dan VII B SMP Taruna Dra. Zulaeha.

\section{Hasil dan Pembahasan}

\section{TABEL 1. HASIL WAWANCARA DENGAN GURU IPA}

\begin{tabular}{ll}
\hline Pertanyaan & Jawaban \\
\hline $\begin{array}{l}\text { Metode apakah yang saat ini digunakan } \\
\text { dalam pembelajaran IPA materi sistem } \\
\text { tata surya? }\end{array}$ & $\begin{array}{l}\text { Karena materi sistem tata surya ini materi akhir- } \\
\text { akhir, jadi biasanya metodenya ya membaca dan } \\
\text { mengerjakan soal untuk mengejar waktu. }\end{array}$ \\
\hline $\begin{array}{l}\text { Bagaimana sikap siswa pada saat } \\
\text { pembelajaran IPA berlangsung? }\end{array}$ & $\begin{array}{l}\text { Siswa kurang antusias dalam pembelajaran karena } \\
\text { proses pembelajaran yang terkesan terburu-buru } \\
\text { dan konvensional. }\end{array}$ \\
\hline $\begin{array}{l}\text { Kendala apa saja yang Bapak hadapi saat } \\
\text { mengajarkan materi sistem tata surya? }\end{array}$ & $\begin{array}{l}\text { Antusiasme siswa yang kurang serta media } \\
\text { pembelajaran yang hanya terbatas pada buku } \\
\text { tanpa bisa mengamati secara langsung baik }\end{array}$ \\
$\begin{array}{ll}\text { Media apakah yang sering Bapak } \\
\text { gunakan pada materi sistem tata surya? }\end{array}$ & $\begin{array}{l}\text { Buku dan media pemebelajaran berupa bola-bola } \\
\text { sistem tata surya. }\end{array}$ \\
\hline $\begin{array}{l}\text { Apakah proses pembelajaran sudah } \\
\text { memanfaatkan perkembangan teknologi }\end{array}$ & $\begin{array}{l}\text { Untuk materi yang lain sudah, namun untuk } \\
\text { materi sisitem tata surya masih terbatas pada }\end{array}$ \\
yang ada sampai saat ini? & buku serta media pembelajaran berupa alat \\
& praktikum yang seringkalai belum bisa terlaksana. \\
\hline $\begin{array}{l}\text { Apakah hingga saat ini pernah dilakukan } \\
\text { pembelajaran dengan menggunakan }\end{array}$ & Belum pernah sampai saat ini. \\
"Multimedia Pembelajaran Interaktif & \\
Berbasis Game Edukasi" & \\
\hline $\begin{array}{l}\text { Apakah menurut Bapak selaku guru IPA, } \\
\text { pengembangan "Multimedia } \\
\text { pembelajaran interaktif pada materi }\end{array}$ & $\begin{array}{l}\text { Sangat butuh mbak. Pertama agar siswa } \\
\text { termotivasi untuk mempelajari materi sistem tata } \\
\text { surya ini yang sebenarnya sangat dibutuhkan }\end{array}$ \\
\hline
\end{tabular}


sistem tata surya" dibutuhkan dalam pembelajaran IPA di SMP Taruna Dra. Zulaeha ini?

\begin{abstract}
dalam kehidupan sehari-hari. Seperti planetplanet beserta ciri-cirinya, akibat rotasi revolusi bulan dan bumi, fase-fase bulan. Hal-hal seperti itu kadang siswa malah tidak faham walaupun telah mempelajari. Jadi, dengan adanya media seperti ini diharapkan siswa semangat dalam belajarnya sehingga akan lebih merasuk kedalam pikiran siswa dan bisa diterapkan dalam kehidupan. Karena tidak menutup kemungkinan jika hal tersebut memang akan ada dan menjadi bahan pembelajaran yang lebih untuk mereka sendiri di lingkungan tempat mereka tinggal.
\end{abstract}

TABEL 2. HASIL WAWANCARA DENGAN SISWA

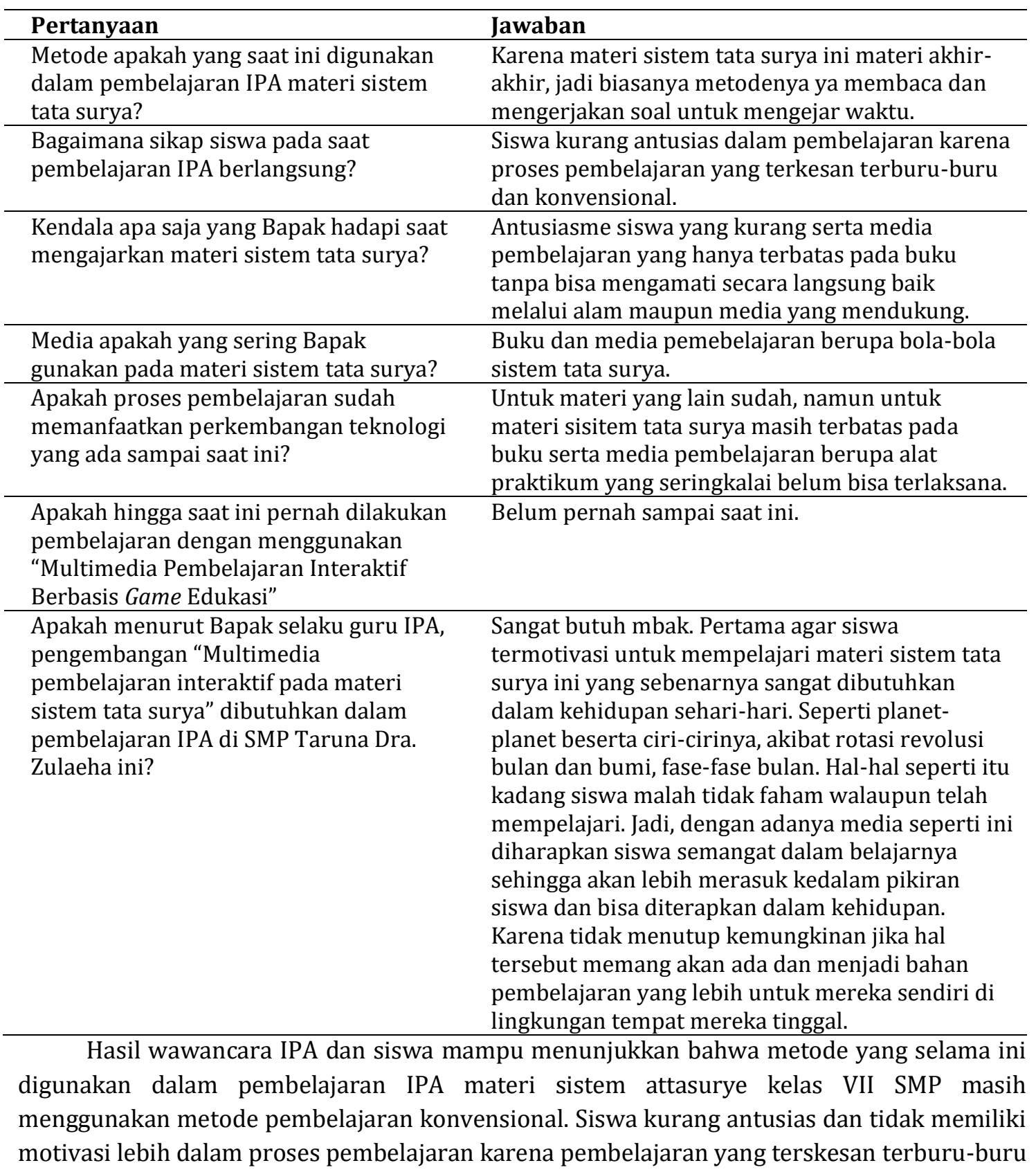


dan hanya berpaku pada buku. Penggunaan multimedia pembelajaran hanya terbatas pada beberapa materi dan tidak semua. Game edukasi merupakan salah satu media pembelajaran yang jarang digunakan dalam proses pembelajaran. Kebutuhan media pembelajaran sangatlah membantu dalam proses pembelajaran.

Hasil observasi dan wawancara yang dilaksanakan kepada guru IPA di SMP Taruna Dra. Zulaeha, diperoleh infromasi bahwa materi IPA kelas VII semester genap adalah sistem tata surya yang merupakan salah satu materi abstrak karena fenomena dan benda langit yang tidak dapat sepenuhnya diamati dengan langsung. Materi ini termasuk dalam KD 3.11 yang menyatakan bahwa siswa harus mampu menganalisis sistem tata surya, rotasi dan revolusi bumi, rotasi dan revolusi bulan, serta dampaknya bagi kehidupan di bumi. Materi sistem tata surya sering kali dikesampingkan karena beberapa faktor yang dihadapi dalam proses pembelajaran, diantaranya kemampuan penguasaan materi, materi yang kurang menarik, kurang ketersediaannya alat peraga yang memadai, serta media pembelajaran masih kurang interaktif.

\section{Simpulan}

\subsection{SIMPULAN}

Hasil penelitian yang dilakukan sesuai penelitian yang dilakukan oleh Sutriyono (2012) bahwa penggunaan multimedia pembelajaran interaktif dinyatakan efektif untuk meningkatkan minat belajar siswa pada materi sistem tata surya. Pengguna multimedia pembelajaran interaktif dengan berbasis game edukasi membuat siswa menjadi lebih antusias dalam mempelajari konsep.

\subsection{SARAN}

Salah satu kegiatan dalam pembelajaran IPA adalah melakukan percobaan. Multimedia pembelajaran interakti berbasis game edukasi perlu disertai dengan praktikum, namun dapat digunakan dalam pembelajaran praktikum untuk memvisualkan materi sistem tata surya yang tidak semua dapat diamati oleh manusia secara langsung.

\section{Daftar Rujukan}

Boeker, M., Andel, P., Vach, W., \& Frankenschmidt, A. (2013). Game-based e-learning is more effective than a conventional instructional method: a randomized controlled trial with third-year medical students. PloS one, 8(12), e82328.

Falahudin, I. (2014). Pemanfaatan media dalam pembelajaran. Jurnal Lingkar Widyaiswara, 1(4), 104-117.

Handhika, J. (2012). Efektivitas media pembelajaran IM3 ditinjau dari motivasi belajar. Jurnal Pendidikan IPA Indonesia, 1(2).

Lestari, P. P., \& Linuwih, S. (2014). Analisis Konsepsi dan Perubahan Konseptual Suhu dan Kalor pada Siswa SMA Kelas Unggulan. UPEJ Unnes Physics Education Journal, 3(2).

Riwahyudin, A. (2015). Pengaruh sikap siswa dan minat belajar siswa terhadap hasil belajar IPA siswa kelas V sekolah dasar di Kabupaten Lamandau. Jurnal Pendidikan Dasar, 6(1), 11-23.

Yien, J. M., Hung, C. M., Hwang, G. J., \& Lin, Y. C. (2011). A game-based learning approach to improving students' learning achievements in a Nutrition course. Turkish Online Journal of Educational Technology-TOJET, 10(2), 1-10. 